\title{
ВЫСОКОТИТАНИСТЫЙ КАЛИЕВЫЙ АМФИБОЛ ИЗ АГПАИТОВЫХ СИЕНИТОВ ИНТРУЗИИ НИВА И ДАЙКИ УЧАСТКА «МОХНАТЫЕ РОГА» (КОЛЬСКИЙ П-ОВ)
}

\author{
Филина М.И., Когарко Л.Н., Кононкова Н.Н. \\ ГЕОХИ РАН, Москва, makimm@mail.ru
}

Натриевые и натрий-кальциевые амфиболы широко распространены в щелочных, особенно агпаитовых породах, пегматитах и метасоматитах, связанных с щелочными интрузиями $[4,5]$. Калий является типичным компонентом многих щелочных амфиболов, но содержание $\mathrm{K}_{2} \mathrm{O}$ обычно не превышает 1-2 мас. \%. В 2004 г. был утвержден новый минеральный вид - калиевый арфведсонит $\mathrm{KNa}_{2} \mathrm{Fe}^{2+} 4 \mathrm{Fe}^{3+} \mathrm{Si}_{8} \mathrm{O}_{22}(\mathrm{OH})_{2}$, найденный в щелочных пегматитах из трех щелочных комплексов: Илимауссакского, Ловозерского и Хибинскиого [7].

Нами были впервые исследованы высокотитанистые калиевые амфиболы из агпаитовых сиенитов интрузии Нива и дайки участка «Мохнатые Рога», расположенных в северо-западной части Беломорского подвижного пояса. Сиениты из этих объектов практически идентичны по химическому и минеральному составу $[1,3]$. Главные минералы агпаитовых сиенитов: калиевый полевой шпат (25-30 об. \%), натролит (10-15 об. \%), эгирин-авгит (10-15 об. \%), энигматит (10-15 об. \%), калиевый амфибол (5-10 об. \%), характерной особенностью породы, является присутствие среди породообразующих минералов в количестве до 20 об. \% минералов группы лампрофиллита (МГЛ): лампрофиллита, фторлампрофиллита, баритолампрофиллита, и фторбаритолампрофиллита. По сравнению с нефелиновыми сиенитами Хибинского и Ловозерского массивов изучаемые породы содержат значительно меньше кремнезема, в то время как содержание железа и титана значительно выше, что отражается в химическом составе породообразующих минералов $[1,3]$.

Амфиболы в породе образуют удлиненные крупные зерна, размером 1-1.5 мм буроватокоричневого цвета, со слабым синеватым оттенком, поперечные реже продольные сечения часто имеют шестиугольную форму. Минерал заметно плеохроирует в зеленовато-бурых и синеватозелёных тонах с обратной схемой абсорбции. В породе амфибол чаще всего ассоциирует с эгиринавгитом, мелкие игольчатые зерна которого, располагаются как по краям, так и внутри кристаллов (рис. 1), также амфибол может располагаться по краям зерен энигматита, и можно предположить, что энигматит по сравнению с амфиболом более ранний.

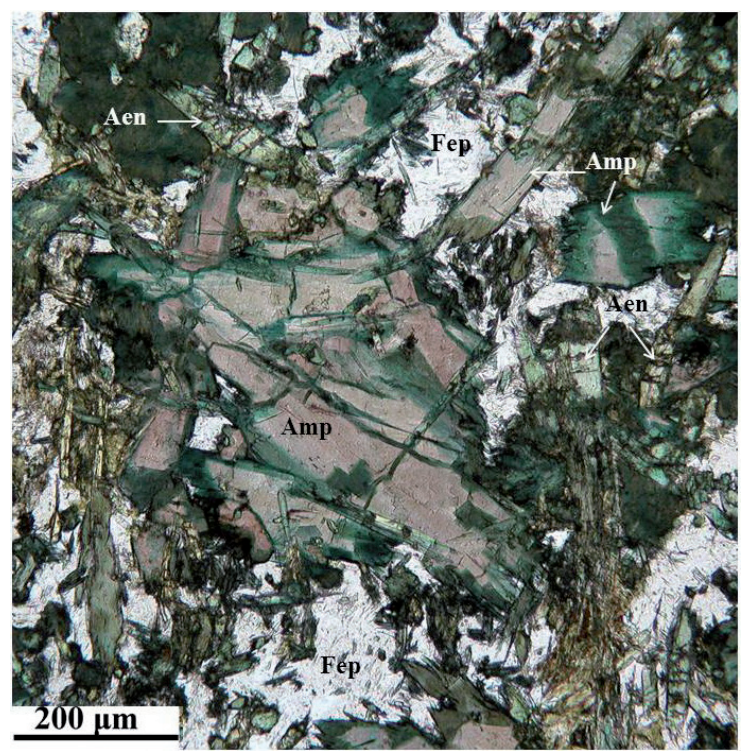

Рис. 1. Скопление кристаллов калиевого амфибола (Amp) в ассоциации с эгирин-авгитом (Aen) в матрице из полевого шпата и натролита (Fep), агпаитовый сиенит интрузии Нива.

Согласно современной классификации группы амфиболов [6], исследуемые амфиболы относятся к натрий-кальциевой и натриевой группе, содержание $\mathrm{K}_{2} \mathrm{O}-3.11-4.81$ вес. \%, что позволяет K доминировать над Na в позиции А. Характерной особенностью исследованных амфиболов является высокое содержание титана - до 4.71 мас. \%, а также фтора - до 3.54 мас. \% (табл. 1). Амфиболы зональные: центральные части по составу соответствуют высокотитанистому калиевому катофориту, калиевому катофориту или высокотитанистому калиевому энкерманиту, краевые части высокотитанистому калиевому арфведсониту или калиевому арфведсониту. Зональность амфиболов выражается в увеличении содержаний натрия, калия, и железа от ядра к периферии, и уменьшении содержаний магния и кальция. Центральные части кристаллов содержат значительные количества титана и фтора, причем содержание фтора, коррелирует с содержанием титана - с уменешением содержания 
титана, уменьшается содержание фтора (табл.1), что свидетельствует высокой активности фтора на начальных стадиях кристаллизации расплава. В экспериментальных работах по исследованию полей устойчивости амфиболов в зависимости от фугитивности кислорода и температуры, показано, что тренд изменения состава амфибола от Са через $\mathrm{Na}-\mathrm{Ca}$ к $\mathrm{Na}$ амфиболам отражает понижение температуры и фугитивности кислорода на уровне или ниже буфера QFM [8].

Таблица 1. Представительные анализы химического состава (мас. \%) зональных кристаллов амфибола из дайки участка Мохнатые рога и интрузии Нива.

\begin{tabular}{|c|c|c|c|c|c|c|c|c|c|}
\hline \multirow{2}{*}{$\begin{array}{c}\text { Компо- } \\
\text { нент }\end{array}$} & 1 & 2 & 3 & 4 & 5 & 6 & 7 & 8 & 9 \\
\hline & $\mathrm{C}$ & $\mathrm{R}$ & $\mathrm{C}$ & $\mathrm{R}$ & $\mathrm{C}$ & $\mathrm{R}$ & $\mathrm{C}$ & $\mathrm{R}$ & $\mathrm{C}$ \\
\hline $\mathrm{SiO}_{2}$ & 52.62 & 50.08 & 49.86 & 48.65 & 50.91 & 49.57 & 51.03 & 50.61 & 50.81 \\
\hline $\mathrm{TiO}_{2}$ & 3.16 & 2.74 & 3.02 & 2.11 & 4.36 & 2.83 & 4.38 & 2.02 & 4.71 \\
\hline $\mathrm{Al}_{2} \mathrm{O}_{3}$ & 0.76 & 0.83 & 0.75 & 0.88 & 1.57 & 0.18 & 1.42 & 0.59 & 1.83 \\
\hline $\mathrm{MnO}$ & 0.52 & 0.33 & 0.53 & 0.27 & 0.46 & 0.72 & 0.55 & 0.60 & 0.53 \\
\hline $\mathrm{FeO}$ & 14.16 & 25.90 & 14.19 & 24.20 & 13.92 & 29.32 & 14.86 & 25.54 & 14.15 \\
\hline $\mathrm{MgO}$ & 12.53 & 5.69 & 12.40 & 6.49 & 11.64 & 1.13 & 11.43 & 4.58 & 11.73 \\
\hline $\mathrm{CaO}$ & 3.11 & 0.79 & 3.05 & 0.75 & 2.86 & 0.06 & 2.97 & 0.22 & 3.35 \\
\hline $\mathrm{Na}_{2} \mathrm{O}$ & 6.43 & 7.06 & 6.36 & 7.15 & 6.72 & 7.21 & 6.63 & 6.88 & 6.44 \\
\hline $\mathrm{K}_{2} \mathrm{O}$ & 3.76 & 4.55 & 3.60 & 4.19 & 3.25 & 4.81 & 3.16 & 4.77 & 3.11 \\
\hline $\mathrm{ZrO}_{2}$ & 0.79 & 0.00 & 0.85 & 0.06 & 0.48 & нпо & 0.12 & нпо & 0.12 \\
\hline $\mathrm{BaO}$ & 0.11 & 0.05 & 0.07 & 0.05 & 0.29 & 0.22 & 0.13 & 0.13 & нпо \\
\hline $\mathrm{SrO}$ & 0.49 & 0.03 & 0.57 & 0.17 & 0.33 & 0.05 & 0.28 & 0.07 & 0.60 \\
\hline $\mathrm{Cr}_{2} \mathrm{O}_{3}$ & но & но & но & но & 0.03 & 0.01 & 0.02 & 0.00 & 0.06 \\
\hline $\mathrm{Nb}_{2} \mathrm{O}_{5}$ & 0.02 & 0.01 & 0.05 & 0.10 & но & но & но & но & но \\
\hline $\mathrm{Ta}_{2} \mathrm{O}_{5}$ & нпо & нпо & 0.12 & нпо & но & но & но & но & но \\
\hline $\mathrm{ThO}_{2}$ & 0.07 & нпо & 0.07 & нпо & но & но & но & но & но \\
\hline $\mathrm{UO}_{2}$ & 0.64 & 0.73 & 0.73 & 0.88 & но & но & но & но & но \\
\hline $\mathrm{F}$ & 3.34 & 0.83 & 3.54 & 1.44 & 3.04 & 0.02 & 3.13 & 0.21 & 2.97 \\
\hline Сумма & 102.51 & 99.62 & 99.76 & 97.39 & 99.86 & 96.13 & 100.11 & 96.22 & 100.41 \\
\hline $\mathrm{O}=\mathrm{F}$ & 1.41 & 0.35 & 1.49 & 0.61 & 1.28 & 0.01 & 1.32 & 0.09 & 1.25 \\
\hline Сумма & 101.10 & 99.27 & 98.27 & 96.78 & 98.58 & 96.12 & 98.79 & 96.13 & 99.16 \\
\hline & & & Формул & ые коэ & ициент & & & & \\
\hline $\mathrm{Na}$ & 0.38 & 0.24 & 0.43 & 0.33 & 0.45 & 0.30 & 0.15 & 0.45 & 0.45 \\
\hline $\mathrm{K}$ & 0.71 & 0.89 & 0.70 & 0.84 & 0.62 & 1.00 & 0.96 & 0.63 & 0.59 \\
\hline $\mathrm{Ca}$ & 0.49 & 0.13 & 0.50 & 0.13 & 0.46 & 0.01 & 0.04 & 0.39 & 0.54 \\
\hline$\Sigma_{\mathrm{A}}$ & 1.09 & 1.14 & 1.13 & 1.17 & 1.07 & 1.30 & 1.12 & 1.08 & 1.05 \\
\hline $\mathrm{Ca}$ & 0.49 & 0.13 & 0.50 & 0.13 & 0.46 & 0.01 & 0.04 & 0.39 & 0.54 \\
\hline $\mathrm{Sr}$ & 0.04 & 0.00 & 0.05 & 0.02 & 0.03 & 0.01 & 0.01 & 0.04 & 0.05 \\
\hline $\mathrm{Na}$ & 1.46 & 1.87 & 1.45 & 1.86 & 1.51 & 1.99 & 1.96 & 1.57 & 1.41 \\
\hline$\Sigma_{\mathrm{B}}$ & 2.00 & 2.00 & 2.00 & 2.00 & 2.00 & 2.00 & 2.00 & 2.00 & 2.00 \\
\hline $\mathrm{Ti}$ & 0.28 & 0.18 & 0.10 & 0.08 & 0.43 & 0.35 & 0.24 & 0.47 & 0.44 \\
\hline $\mathrm{Zr}$ & 0.06 & - & 0.06 & 0.01 & 0.04 & - & - & 0.01 & 0.01 \\
\hline $\mathrm{Al}$ & - & - & - & - & - & 0.04 & 0.11 & - & - \\
\hline $\mathrm{Fe}^{3+}$ & - & 0.79 & 0.40 & 1.02 & - & - & 0.48 & - & - \\
\hline $\mathrm{Mn}^{2+}$ & 0.07 & 0.04 & 0.07 & 0.04 & 0.06 & 0.10 & 0.08 & 0.08 & 0.07 \\
\hline $\mathrm{Fe}^{2+}$ & 1.75 & 2.54 & 1.41 & 2.17 & 1.75 & 4.01 & 2.89 & 2.08 & 1.77 \\
\hline $\mathrm{Mg}$ & 2.77 & 1.31 & 2.82 & 1.52 & 2.61 & 0.28 & 1.08 & 2.27 & 2.61 \\
\hline
\end{tabular}




\begin{tabular}{|c|c|c|c|c|c|c|c|c|c|}
\hline гоктаэдр & 4.92 & 4.87 & 4.87 & 4.83 & 4.89 & 4.77 & 4.89 & 4.90 & 4.90 \\
\hline $\mathrm{Si}$ & 7.79 & 7.71 & 7.62 & 7.66 & 7.66 & 8.10 & 8.00 & 7.69 & 7.59 \\
\hline $\mathrm{Al}$ & 0.13 & 0.15 & 0.14 & 0.16 & 0.28 & - & - & 0.26 & 0.32 \\
\hline $\mathrm{Ti}$ & 0.08 & 0.14 & 0.25 & 0.17 & 0.06 & - & - & 0.05 & 0.09 \\
\hline$\Sigma_{\text {тетраэдер }}$ & 8.00 & 8.00 & 8.00 & 8.00 & 8.00 & 8.10 & 8.00 & 7.99 & 8.00 \\
\hline $\mathrm{OH}$ & 0.44 & 1.60 & 0.29 & 1.28 & 0.55 & 1.99 & 1.90 & 0.73 & 0.60 \\
\hline $\mathrm{F}$ & 1.56 & 0.40 & 1.71 & 0.72 & 1.45 & 0.01 & 0.11 & 1.27 & 1.40 \\
\hline$\Sigma_{\mathrm{w}}$ & 2.00 & 2.00 & 2.00 & 2.00 & 2.00 & 2.00 & 2.00 & 2.00 & 2.00 \\
\hline
\end{tabular}

Примечание. 1-4 - амфиболы из дайки участка Мохнатые Рога (образцы № 11-Юк-8, 11-Юк-32). 5-9 - амфиболы из интрузии Нива (образцы № H-8-1, H-8-3 ). Зоны кристаллов: C - центральная. R- краевая. нпо - ниже предела обнаружения, но - не определялось. Формульные коэффициенты рассчитаны на $24(\mathrm{OH}, \mathrm{F}, \mathrm{Cl}, \mathrm{O})$. Значения содержания ОН получены исходя из условия электронейтральности.

Также эволюция составов амфибола соответствуют общей направленности эволюции составов пироксенов в изучаемом агпаитовом сиените [2]. Зональность пироксенов выражается в увеличении содержаний натрия, железа и титана от ядра к периферии, и уменьшении содержаний магния и кальция. Пироксены также содержат значительные количества титана до 6.05 мас. \% $\mathrm{TiO}_{2}$ в краевых частях кристаллов, что позволяет отнести его к титанистому эгирин-авгиту.

На примере эволюции состава породообразующих минералов из щелочных комплексов, можно исследовать эволюцию магматических систем от ранних этапов до поздних стадий, которые контролируются такими факторами, как состав магматического расплава, фугитивность кислорода, щёлочность, температура минеральных равновесий и др.

Работа выполнена за счет средств выделенных на выполнение госзадания.

\section{Литература}

1. Акименко М. И., Когарко Л. Н., Сорохтина Н. В., Кононкова Н. Н., Мамонтов В. П. Новое проявление щелочного магматизма на Кольском полуострове, агпаитовая дайка в Кандалакшском районе // Докл. АН. 2014. № 458 С. 193-197.

2. Филина М. И., Когарко Л. Н., Кононкова Н. Н. Эволюция пироксенов в высокощелочных магматических системах на примере дайкового комплекса агпаитовых сиенитов и интрузии Нива (Кольский полуостров) // Геохимия. 2017. № 7. С. 653-659.

3. Arzamastsev A.A., Belyatskiy B.V., Arzamastseva L.V. Agpaitic magmatism in the northeastern Baltic Shield: a study of the Niva intrusion, Kola Peninsula, Russia // Lithos. 2000. № 51. P. 27-46.

4. Deer,W. A., Howie, R. A., Zussman, J. Rock-Forming Minerals // London, Geol. Soc.: Volume 2B DoubleChain Silicates. 1997. 764 pp.

5. Hawthorne, F. C. The crystal chemistry of the amphiboles: V. The structure and chemistry of arfvedsonite // Canadian Mineralogist. 1976. № 14. P. 346-356.

6. Hawthorne F.C., Oberti R., Harlow G. E., Maresch W. V., Martin R. F., Schumacher J. C., Welch M. D. IMA Report Nomenclature of the amphibole supergroup. American Mineralogist // 2012.V. 97. P. 2031-2048.

7. Pekov I.V., Chukanov N.V., Lebedeva Yu.S., Pushcharovsky D.Yu., Ferraris G., Gula A., Zadov A.E., Novakova A.A., Petersen O.V. Potassicarfvedsonite, $\mathrm{KNa}_{2} \mathrm{Fe}_{2}+4 \mathrm{Fe}_{3}+\mathrm{Si}_{8} \mathrm{O}_{22}(\mathrm{OH})_{2}$, a K-dominant sodic amphibole of the arfvedsonite series from agpaitic pegmatites - Mineral data and type of disorder in the A site // Neues Jahrbuch für Mineralogie - Monatshefte. 2004. № 12. P. 555-574.

8. Mitchell R.H. A review of the compositional variation of amphiboles in alkaline plutonic complexes // Lithos. 1990. P. 135-156. 